\title{
Apologia de Eurípides: literatura e conhecimento em Aqueles cães malditos de Arquelau, de Isaías Pessotti
}

\section{Apology of Eurípides: literature and knowledge in Isaías Pessotti's Aqueles cães malditos de Arquelau}

Anelito de Oliveira *

anelitoeoliveira@globomail.com

Universidade Estadual de Montes Claros (Unimontes)

\begin{abstract}
RESUMO: Em 1993, Isaías Pessotti, nome já de destaque no campo da psiquiatria, deu um passo significativo no seu trabalho de romancista com a publicação de Aqueles cães malditos de Arquelau. No ano seguinte, Ivani C. Arantes Fazenda publica Interdisciplinaridade, apresentando um instigante balanço sobre a questão do método no campo das ciências humanas dos anos 1970 até aquele início da última década do século passado. Este texto reflete sobre o romance de Pessotti a partir de toda a provocação advinda do livro de Fazenda, visando, especialmente, colocar em relevo a problemática relação entre produção literária e produção científica no contexto latino-americano.
\end{abstract}

PALAVRAS-CHAVE: Interdisciplinaridade. Literatura. Ciência. Romance. Isaías Pessotti.

ABSTRACT: In 1993, Isaias Pessotti, an already prominent name in the field of psychiatry, took a significant step in his work as a novelist with the publication of Aqueles cães malditos de Arquelau. The following year, Ivani C. Arantes Fazenda published Interdisciplinarity, presenting an instigating review on the question of method in the field of human sciences from the 1970s to that beginning of the last decade of the last century. This text reflects on Pessotti's novel, stemming from all the provocation from Fazenda's book, aiming, in particular, to highlight the problematic relationship between literary production and scientific production in the Latin American context.

KEYWORDS: Interdisciplinarity. Literature. Science. Novel. Isaías Pessotti.

\footnotetext{
* Doutor em Literatura Brasileira pela Universidade de São Paulo (USP); Pós-Doutor em Teoria Literária pela Universidade Estadual de Campinas (UNICAMP); Professor na Universidade Estadual de Montes Claros (UNIMONTES).
} 


\section{Pressupostos}

Discursos que se elaboram a partir de um horizonte de interdisciplinaridade, precisamente dos anos 1960 para cá, acabam por experimentar uma situação incômoda em relação à ordem tradicional do saber ainda bastante estável, àquilo que se entende por ciência na civilização ocidental. Este é o primeiro pressuposto deste trabalho. Esses discursos se mostram pouco à vontade diante da ciência justamente porque o que motiva a interdisciplinaridade é, sobretudo, aquilo que sempre foi deixado de lado pela ciência, a incerteza, a dúvida, a sombra. Com o privilégio de ser o campo da verdade, que lhe é conferido pelas instituições que administram o processo de produção de conhecimento acadêmico, especialmente a Universidade, a ciência constitui entrave natural à legitimação de discursos interdisciplinares, transdisciplinares ou multidisciplinares, para aludir a variantes mais recentes do mesmo horizonte interdisciplinar.

A interdisciplinaridade encontra na nossa lógica cultural o principal obstáculo à sua afirmação e, por isso mesmo, propõe-se como crítica a essa lógica, tentando substituí-la por outra - eis meu segundo pressuposto. Criticar a lógica cultural, por sua vez, exige uma mudança de paradigma no processo de sistematização do saber. O paradigma antropofágico, concebido por Oswald de Andrade, é o que se apresenta, implícita ou explicitamente, nas práticas discursivas interdisciplinares no Brasil, a meu ver. Procuro detectar a presença desse paradigma no romance Aqueles cães malditos de Arquelau, de Isaías Pessotti. Leio essa presença como crítica à razão racionalizante e, consequentemente, abertura, pela "práxis" literária, de novas possibilidades de verdade.

Um terceiro pressuposto deste trabalho é que a interdisciplinaridade, ou multidisciplinaridade, traz à tona a possibilidade de uma alteração decisiva da ordem do saber, culminando num princípio de relatividade de toda verdade. A interdisciplinaridade coloca em xeque a verdade absoluta do filósofo tradicional ou do cientista positivista, fruto de uma concepção harmônica do real. Em contrapartida, a interdisciplinaridade recoloca em circulação verdades ambíguas, aquelas que constituíram a palavra do poeta na Grécia antiga, verdades apaixonadas, nas quais se mesclam saber e sabor. Disso, em especial, decorreria a compreensão negativa da interdisciplinaridade como ameaça à ordem do saber - tratar-se-ia de uma 
desordem na cena do saber. A interdisciplinaridade, como o trágico Eurípides figurado pela narrativa de Pessotti, desestabiliza nossa lógica cultural.

\section{Ciência e existência}

Nos anos 1970, a interdisciplinaridade buscou "uma explicitação filosófica", nos anos 1980, "uma diretriz sociológica", e, nos anos 1990, "um projeto antropológico", segundo Ivani Fazenda (1994, p. 17). Vê-se nesse percurso um movimento da teoria à prática, uma passagem do plano do "logos" em si para o plano do humano, uma mudança de foco naturalmente "forçada" por questões contextuais. Essa passagem não parece implicar uma saída harmônica para a interdisciplinaridade, uma solução para o problema metodológico que ela mesma é e para outros problemas que dela advieram. Ao contrário: chegando ao plano do homem é que a interdisciplinaridade realmente encontra um problema: ela já não é apenas uma estratégia discursiva para falar de objetos exteriores ao sujeito do discurso: aquele que fala interdisciplinarmente também se inclui no que está sendo falado.

O rompimento com o mito da objetividade que alimentava as ciências humanas e sociais, herança "maldita" do naturalismo dos séculos XVIII e XIX, permitiu o voo da interdisciplinaridade na sua alvorada, mas acabou por policiar esse voo nos anos 1990, por discipliná-lo, paradoxalmente. "A ciência questionada em suas objetividades", salienta Fazenda (1994, p. 15), "não encontra pátria nas atuais subjetividades". Com o que essa autora chama de "provisoriedade da verdade e da ciência", trazida pelo método interdisciplinar, passa a existir "a possibilidade de um real encontro entre ciência e existência”, mas não me parece ser um encontro, em termos antropofágicos, entre a fome e a vontade de comer, a reconciliação entre o mesmo e o outro, mas um encontro de "forças inimigas", para lembrar passagem expressiva de Laymert Garcia dos Santos (1989, p. 13).

Ciência e existência, como não se ignora, nunca tiveram um relacionamento harmônico na civilização ocidental - e, se a mudança radical desta situação fosse totalmente possível, talvez jamais teria vindo à tona sequer a ideia de interdisciplinaridade: somente o diálogo entre esses dois planos da realidade já configuraria uma relação interdisciplinar. A contradição entre o que se vive e o que se diz, entre realidade e discursividade, parece se colocar na base da dicotomia 
entre ciência e existência principalmente em lugares como América Latina, nas periferias dos grandes centros capitalistas. A existência, tudo aquilo que o homem experiencia em sua cotidianidade, é sempre mais complexa que a ciência, que um discurso sobre determinado objeto. Há, especialmente na prática da ciência em clave positivista, uma tendência à simplificação, à diluição de complexidades em nome de um suposto bom funcionamento da "polis".

Superar a "dicotomia ciência/existência" é uma necessidade que Fazenda (1994, p. 14) identifica nos teóricos da interdisciplinaridade. Mas o próprio processo de superação dessa dicotomia parece estar fadado a se apresentar como encenação de uma crise de identidade da interdisciplinaridade. Se a ciência, cuja crise estimulou o surgimento da interdisciplinaridade, "não encontra pátria nas atuais subjetividades", a interdisciplinaridade também não encontra pátria nas objetividades que continuam a legitimar uma gama de discursos como ciência. A interdisciplinaridade, então, perturba a ordem da ciência, mas leva consigo um pouco dessa perturbação simplesmente porque as coisas, no Ocidente, precisam estar apoiadas num lugar, numa "pátria", numa ordem, para serem verdadeiras, críveis. A interdisciplinaridade, no seu desenvolvimento, acercou-se desse lugar como o próprio humano, num movimento da exterioridade à interioridade, como argumenta Ivani Fazenda (1994, p. 15)

Passados os momentos de sua concepção e disseminação, não me parece que a interdisciplinaridade possa se sustentar como método eficiente de produção de conhecimento hoje, num novo século, sem que apresente sua pertinência cultural, sem que revele o alicerce em que se apoia na realidade latino-americana em geral e brasileira, em especial. Essa pertinência, paradoxalmente, parece proceder daquilo que a cultura acadêmica ainda fundamentada no positivismo tende a considerar impertinente, a-científico, "pessoal". A afirmação da interdisciplinaridade acaba por impor a negação da lógica cultural dominante, uma mudança radical de paradigma, o que não significa, por outro lado, possibilidade de acomodação do discurso interdisciplinar no âmbito da ciência institucional. Pode-se falar num dilema da interdisciplinaridade hoje semelhante ao que Roland Barthes (1988. p. 26) identificou no Estruturalismo em 1967.

\section{0 paradigma antropofágico}


A lógica cultural, evidentemente, não é a mesma em todos os lugares, motivo básico de tanta convergência quanto divergência na percepção do real por diferentes sujeitos, resultantes de experiências diferentes. Disso decorre que o sentido de interdisciplinaridade, bem como finalidades dessa prática na esfera do conhecimento, não pode ser o mesmo por toda parte. O "projeto antropológico" da interdisciplinaridade não pode deixar de ser diferente na América Latina e na Europa, no Brasil e em Cuba, porque há diferenças entre os que habitam esses lugares. Mais que reconhecer essas diferenças, é fundamental que o método interdisciplinar proceda a uma radicalização na produção de conhecimento a partir dessas diferenças, procurando sempre intensificá-las.

Um ponto de convergência que se encontra facilmente entre os que operam o pensamento crítico pelo viés da interdisciplinaridade diz respeito ao lugar do discurso, à posição do sujeito cognoscente. Não se trata de um lugar de certezas, ordenado, inabalável. Esse lugar se assemelha à noção de pátria enunciada por $\mathrm{E}$. Cioran (1994, p. 12): a pátria é "apenas um acampamento no deserto". Lugar provisório, onde o discurso está sempre "sujeito a reboque", a desestabilizações. Nisso parecem convergir Barthes, Silviano Santiago, Jacques Derrida, Michel Butor e Stuart Hall, por exemplo. A "divergência", a particularidade, insinua-se na finalidade que cada sujeito apresenta, motivada, penso eu, pela qualidade da experiência com o real. A percepção de mundo por um europeu ou norte-americano, naturalmente, não é nem poderia ser a mesma de um latino-americano. $O$ fundamento dessa diferença de percepção é de ordem político-identitária, conforme argumenta, em face da América Latina, Wander Melo Miranda (1995, p. 10).

Esta linha de raciocínio pode servir à fundamentação de um sentido produtivo de prática interdisciplinar entre nós: sem abolir as particularidades locais, que constituem traços diferenciantes da identidade latino-americana, podemos trabalhar essas particularidades numa relação dialética, digamos, com as "universalidades" impostas pelo processo de colonização, "empoderadas", em certos casos, pela atual globalização.

Ao trazer à tona essa questão do nacional, não estou fazendo nada mais do que retornar à aurora da interdisciplinaridade no Brasil, despertando o recorte político que a alimentou nos anos 1960. É justamente esse recorte que parece atestar a diferença da perspectiva interdisciplinar em relação a uma perspectiva puramente científica. Esta se satisfaz com a solução de coisas, num processo de 
cultivo de certezas. A perspectiva interdisciplinar não quer apenas solucionar, mas sim problematizar o objeto em questão. Pode-se dizer, com o amparo de Foucault (1990, p. 404), que a pureza científica constitui uma política do mesmo, ao passo que a perspectiva interdisciplinar constituiria uma política do outro. A interdisciplinaridade avança num momento em que se altera a percepção do outro, em que um novo olhar se abre para o outro, em que se acirra o desejo de reconhecimento da alteridade, conforme elucida Frederic Jameson (1992, p. 95).

Por onde a "política da alteridade" passou, a interdisciplinaridade, como "motor" dessa política, parece ter adquirido uma determinada configuração, realizando-se com as "particularidades nacionais". Luiz Costa Lima (1986, p. 218) narra a aurora da interdisciplinaridade no Brasil nos seguintes termos, ressaltando a redescoberta, no final da década de 60, de "Oswald de Andrade pelos poetas concretos e pelo diretor de teatro José Celso Martinez". A interdisciplinaridade no Brasil instaura um processo de redescobrimento do próprio país. Na base desse processo, estimulando a "tomada de posição crítica", está a ideia de antropofagia sistematizada por Oswald de Andrade. Internacionalizar a cultura, a meu ver, não soou plausível naquele país dos anos 60 pelo fato de que seria fazer ciência; problematizar a cultura, por outro lado, seria praticar a interdisciplinaridade. Ser cientista, assim, passou a significar ser colonizado, uma vez que a ciência era e continua sendo o campo do "positivismo messiânico"; ser interdisciplinar passou a significar ser libertário, pensar com a própria cabeça - e coração. A interdisciplinaridade, em função da nossa particularidade antropofágica, reconhece a verdade no discurso do poeta:

Só a Antropofagia nos une. Socialmente. Economicamente. Filosoficamente. (...) Tupi or not tupi that is the question (...) O que atropelava a verdade era a roupa, o impermeável entre o mundo interior e o mundo exterior. A reação contra o homem vestido. $O$ cinema americano informará (...) Foi porque nunca tivemos gramáticas (...) Mas nunca admitimos o nascimento da lógica entre nós (...) Contra o mundo reversível e as ideias objetivadas. Cadaverizadas. O stop do pensamento que é dinâmico. O indivíduo vítima do sistema. Fonte das injustiças clássicas. Das injustiças românticas. E o esquecimento das conquistas interiores (...) A alegria é a prova dos nove. No matriarcado de Pindorama (ANDRADE, 1990 , p. 47-51).

O advento da interdisciplinaridade na cena acadêmico-cultural brasileira pode ser interpretado como um desvio na ordem tradicional do saber e, por conseguinte, 
uma abertura da dimensão "saborosa" desse saber, para lembrar o célebre jogo de Roland Barthes (1977). Pode-se pensar - e aqui está a justificativa da evocação dos anos 60 via Jameson e Costa Lima, sinalizando para a repressão praticada pela ditadura militar - que a interdisciplinaridade corresponde a uma espécie de proclamação de independência em relação à ciência, um grito de liberdade do colonizado aos ouvidos do colonizador.

Entretanto, essa independência não se deu completamente, já que continuamos "prisioneiros" da lógica ocidental, já que são as instituições, como a Universidade, que empregam pesquisadores. É uma independência relativa, mas considerável à medida que permite aflorar uma consciência crítica que pode, inclusive, questionar a pertinência da ciência: o "empregado" pode colocar em xeque o direito que o "empregador" tem sobre ele.

A lógica da interdisciplinaridade, entre nós, parece ter aberto um horizonte para o abalo, senão a derrubada, do "veto ao imaginário" de que fala Costa Lima (1986). Investir contra esse veto, confrontá-lo, parece-me requisito básico para a legitimação do que se diz a partir do viés da interdisciplinaridade. O que se tem como científico, na maioria das vezes, tende a desmentir, ou pelo menos impedir que se ouça com mais atenção, o que se faz de forma interdisciplinar. Conforme Lima (1986, p. 189),

O veto ao imaginário, a consequente domesticação do ficcional, têm sido forças presentes no Ocidente desde os primeiros sinais de descoberta da individualidade moderna, já em fins da Idade Média. O direito de expressão de um eu, não subordinado previamente aos valores (então teológicos) estabelecidos, aparecia como uma ameaça à propagação da verdade.

\section{Contestação de Sócrates}

Minha intenção, a partir de agora, é identificar uma encenação dessa luta contra o veto ao imaginário no romance Aqueles cães malditos de Arquelau, de Isaías Pessotti (1993). Parto do pressuposto de que o fundamento básico dessa luta, no romance, é o mesmo se encontra, implícita ou explicitamente, em textos teóricos concebidos a partir do viés interdisciplinar no Brasil desde os anos 1960: a antropofagia. Esta, que entendo como uma das nossas particularidades nacionais, constitui aquilo que Costa Lima (1986, p. 237) chama de "mancha biográfica", a identidade de quem escreve, a diferença, no livro de Pessotti. Deve-se à mancha 
biográfica, à brasilidade do autor, o abalo da ordem do saber no romance, a configuração de uma visada interdisciplinar.

O romance já se abre atestando a postura crítica do narrador Emílio em relação àquilo que poderia ser chamado de real protagonista da trama: o conhecimento. O leitor é informado de que

Qualquer pesquisador sabe que, para obter financiamentos, é preciso que seu trabalho conduza a "avanços tecnológicos de vanguarda" ou "resultados relevantes para a realidade nacional na área em apreço". Como se verá, o nosso trabalho, diante desses critérios, era fulgurante inutilidade (PESSOTTI, 1993, p. 7).

Essa postura crítica vai-se intensificar a partir de um deslocamento do narrador e seus colegas de pesquisa no Instituto Galilei, já denunciados nesse "nosso trabalho", para um ambiente antropofágico, o "Menarost, uma velha trattoria de aldeia, honesta e tranquila", lugar onde se come, lugar do sabor, portanto. Ali, no momento em que recebem a "fagianella" preparada pela cozinheira Lisa, depois de ouvirem admirados a teoria de seu marido Giulio sobre aquele prato, diz o narrador:

Naquele momento um turbilhão de ideias me passou pela cabeça. Coisas como: a beleza do que é simples, a majestade da figura feminina, a superioridade das coisas genuínas, verdadeiras, a duvidosa validade do saber acadêmico, a alienação do intelectual, as "Bucólicas" de Virgílio, as delícias de uma mulher apaixonada, a nave central de Westminster, como seria uma noite com Lisa, como Giulio era feliz... E se Anna deixasse o marido?... Estacionei gostosamente nessa última ideia (PESSOTTI, 1993, p. 30-31).

A trattoria permite que o narrador passe da ordem da ciência, cuja metáfora espacial é o Galilei, à desordem de sua existência. O desejo, as inquietações humanas frequentemente consideradas secundárias pelo racionalismo científico, passa a ocupar o primeiro plano da cena. Antes da trattoria, existia o pesquisador Emílio, frustrado por não corresponder à expectativas da ciência no artigo que escrevera, agora passa a existir o homem Emílio, para quem o mais importante é o sentimento. O rito antropofágico - comer num restaurante - conduz o sujeito ao encontro de uma consciência crítica sobre o saber tal que qual este é sustentado por instituições como o Galilei ("a duvidosa validade do saber acadêmico"). Em contrapartida, a antropofagia permite a Emílio a descoberta do outro para além do horizonte de razão racionalista, num nível de sensação, de prazer, no corpo: 
E havia também a sensação visceral, ventral de calor e de gozo. Havia a carne, sucos, odores acres atenuados, e os damascos, mornos, rosados e úmidos como mucosas excitadas. Eu ouvia deliciado os suspiros mansos, quase gemidos, de Anna, a cada bocado, o sabor e o prazer de deglutir. Ela estava toda entregue ao prazer.

Percebi naquele momento tudo o que há de fágico no amor. Toda a atávica oralidade do sexo, o sentido do morder, do beijar, e do lamber. $\mathrm{O}$ instinto primário e primitivo de absorver, sugar e engolir o objeto de desejo, de prazer. $E$ enquanto me entregava a esses delírios que o faisão de Lisa me inspirava, tive vontade de abraçar Anna, agora com doçura, sem o ímpeto do desejo, quase como se abraça a mulher amada, depois do amor (PESSOTTI, 1993, p. 3132).

É significativo que o outro de Emílio seja feminino, uma mulher, Anna. A atenção que, gradativamente, ela passa a receber do narrador acaba por configurar uma imagem de relação conflituosa entre mulher e conhecimento. Pode-se dizer que a mulher, pelo fato de sempre ter estado à margem na civilização ocidental, desperta o sujeito para outra margem do conhecimento: a margem da paixão. Anna é, assim, a via interdisciplinar, aquela que permite que ao pesquisador pensar sem que precise abandonar seus sentimentos, liberta-o das garras do racionalismo. Depois de discutir com Tulio e Mauro o pensamento platônico, reflete Emílio:

Agora, a vaga suspeita de uma distorção astronômica no fluxo do saber, por obra das preferências "acadêmicas" de Platão e, como xeque-mate, a informação luminosa de que Anna era a saída para todas essas perplexidades. (...) Anna, depois do Minearost, podia entrar em meu pensamento sob as mais variadas figuras. Mas, como anjo, não dava. Mesmo (PESSOTTI, 1993, p. 36).

Ao negar a possibilidade de Anna entrar em seu pensamento como "anjo", Emílio descarta, em clave cristã, o racionalismo de base orientação platônica (BRUNA, 1991, p. 10) e anuncia a defesa de Eurípides que fará no decorrer do livro, que corresponderia à defesa de um horizonte considerado irracional pela tradição filosófica ocidental. Nessa defesa, Emílio postula o direito ao amor sobre todas as convenções - o casamento, por exemplo - e o direito ao exercício da ciência sem o sacrifício da sensibilidade. Eurípides é elevado, paulatinamente, à dimensão de imagem de um espaço de interdisciplinaridade. Nesse espaço, pode-se dizer que Emílio e Anna se tornam mais do que personagens de um romance: tornam-se sujeitos alegóricos da cena contemporânea do conhecimento, representações de um 
mal-estar que experienciamos em relação ao racionalismo, especialmente em relação ao poder disciplinar que este constitui.

Em Aqueles cães malditos de Arquelau, é a personagem Anna quem detém e enuncia o conhecimento sobre Eurípides, pelo fato de o teatro grego antigo constituir seu objeto de pesquisa. Anna é, portanto, a "mãe" de Eurípides, aquela que o traz à luz, que o tira da sombra e o anuncia, que o torna presente entre a comunidade científica, isto é, Emílio e seus colegas. Este fato é importante à medida que ressalta o papel ativo da mulher na cena do saber, mais ainda por se tratar de outro papel: o de mediadora do acesso a outra verdade, cuja referência é Eurípides. Este se torna, no discurso de Anna, um argumento em favor da viabilidade do matriarcado oswaldiano, lugar onde a mulher teria ascendência sobre os demais. Diz Anna:

A imagem que tenho de Eurípides é a de um homem muito à frente do seu tempo e, simultaneamente, a marca desse tempo (...) De fato, nenhum de seus mestres tão ilustres reunia à sabedoria e à elevação ética tanta criatividade, tanta sensibilidade e, mais que isso, tanto respeito e interesse pelas paixões dos homens (...) ele era um filósofo, ligado ao grupo dos sofistas, era um dos Sophoi. E o próprio Apolo de Delfos, consultado sobre a Sophia de Eurípides, comparada à de Sófocles, respondeu que, se este era um sábio, Eurípides era muito mais: Sophóteros Eurípides. Esse é o Eurípides que eu amo (PESSOTTI, 1993, p. 100).

A volta ao matriarcado começa a ser defendida por Oswald de Andrade em 1928, no seu "Manifesto Antropófago", tema retomado e aprofundado pelo autor, em 1950, na tese "A crise da filosofia messiânica". Voltar ao matriarcado equivaleria a voltar ao espaço de liberdade do homem, lugar onde todos estariam livres das amarras da civilização ocidental. O "Manifesto antropófago" proclama "contra a realidade social, vestida e opressora, cadastrada por Freud - a realidade sem complexos, sem loucura, sem prostituição e sem penitenciárias do matriarcado de Pindorama" (ANDRADE, 1990, p. 52)

O matriarcado, "mundo do homem primitivo", segundo Andrade (1990, p. 102104) desenvolve na tese, "produziu uma cultura antropofágica". A ruptura com esse mundo, com a instauração do patriarcado, "produziu-se quando o homem deixou de devorar o homem para fazê-lo seu escravo".

Pode-se dizer que, em Aqueles cães malditos de Arquelau, Anna é quem anima a re-produção de uma cultura antropofágica, uma nova lógica, com o corpo e a cabeça - e a boca - agindo no restaurante. Anna traz para a cena aquela 
subjetividade que Andrade (1990, p. 142) detecta no matriarcado e Eurípides passa a ser uma espécie legitimação dessa subjetividade. Emílio, desta forma, vê unido o útil ao agradável, o saber e o sabor andando de mãos dadas. Anna é o principal estímulo que Emílio passa a ter, por exemplo, para traduzir o texto de Lutércio sobre Eurípides. Trazer este à tona significa, para Emílio, instaurar outra ordem de verdade, já que a verdade do trágico grego é, como diz Anna, "a paixão" (PESSOTTI, 1993, p. 120). Eurípides permite a Emílio sair da "prisão" do racionalismo ocidental e entrar na "liberdade" do sentimento. Diz Emílio:

Continuei, encorajado por minha indignação com a proscrição de Eurípides, pela lembrança, já quase vaga, de que Anna me amava e pelos fluidos superiores que a cevada deve conter: "o racionalismo de Sócrates desclassificou a paixão e o sentimento, transformandoos em pouco mais do que uma mochila de pedras a ser carregada na subida íngreme da perfeição noética, voilà, e ética. Nada de contradições. O mundo é ordenado e a vida também. Então a filosofia deve ser exposta sem paradoxos, sem contradições, sem incoerências. Ora, tudo isso era o que Eurípides não podia aceitar. Ele apontava justamente a inconsistência entre as ideias e a natureza das coisas, o paradoxo da grandeza impotente do ser humano, a convivência desordenada entre a generosidade e a mesquinharia. E a beleza da racionalidade ao lado da realidade inexorável do irracional, do acaso, do evento. Uma vez proscrita a paixão, nem a Academia, nem o Liceu, podiam enxergar, nas tragédias de Eurípides, algo mais que um duvidoso divertimento (PESSOTTI, 1993, p. 156)

A crítica ao racionalismo de Sócrates, com que Emílio começa a sua defesa de Eurípides, é um dos pontos básicos enfocados na tese "A crise da filosofia messiânica". Para Oswald de Andrade, Sócrates, com "sua militante impostura patriarcalista",

representa a perda do caráter lúdico no homem evoluído (...) Sócrates é o animador da censura, é o patrono da literatura dirigida. Nas suas mãos morrem poesias e arte na Grécia (...) Sócrates é oposição a toda medida eufórica que os gregos guardavam de sua alta antiguidade. Contra o politeísmo, ele lança o Deus único. Contra o sentido precário da vida de Heráclito, ele lança a imortalidade da alma (...) De Sócrates sai o esquema do perfeito boneco humano, longamente exaltado pelas classes dominadoras, a fim de se conservar, domado e satisfeito, o escravo. (ANDRADE, 1990, p. 114117) 
Assim, a contestação do que se poderia chamar de "espaço socrático", a tirania da razão no Ocidente, vai-se apresentando como primeiro requisito para a ressurreição de Eurípides, a emergência da emoção no trabalho com o intelecto.

\section{0 sabor de Medéia}

Em Aqueles cães malditos de Arquelau, o narrador Emílio, traduzindo o texto de Lutércio, toma conhecimento do privilégio que as mulheres têm na obra de Eurípides. Lutércio, defendendo o trágico grego da acusação de misoginia, conduz seu leitor-tradutor a um novo saber sobre a mulher, que passa pelo corpo, mas a ele não se restringe. Emílio percebe que o enfoque da mulher por Eurípides atendia a outras intenções, principalmente a de redirecionar, ressistematizar, a noção de verdade. A partir da mulher, Eurípides coloca em circulação outra racionalidade, um novo modo de concepção do real, liberta um horizonte "aprisionado" pelo racionalismo. Via Lutércio, Emílio redescobre a mulher:

$\mathrm{Na}$ verdade, a mulher que Eurípides retrata, e que o fascina, é diversa da que Aristófanes conhece, mera seguidora de normas e destinos, estrangeira no mundo da paixão, inerte no intelecto. Simples cumpridora de destinos.

A mulher, de certo modo, assume na tragédia de Eurípides o lugar dos antigos heróis (...) porque a grande aventura humana já não consiste no desafio ao destino ou aos deuses, ou no morrer por sua pátria...

É natural que quando o ideal tradicional de homem desmoronava, o olhar agudo de Eurípides procurasse na mulher, confinada a uma condição subalterna, pela moral e pelos costumes, a expressão mais pura da crise entre o nomos e o pathos, já que ela não tinha por que sentir-se desorientada pela decadência de um modo de vida no qual o seu papel era o da submissão. E aparecia, na crise, como a forma acabada da condição humana real, com seus direitos, entre eles o direito febril à paixão (PESSOTTI, 1993, p. 110-112).

Creio ser produtivo pensar nessa redescoberta da mulher como redescoberta da verdade que o racionalismo socrático conseguiu soterrar na civilização ocidental. Pode-se que a redescoberta dessa verdade que vem da mulher é um dos principais intuitos da "mancha biográfica" no romance de Isaías Pessotti. Meu raciocínio se organiza da seguinte forma em torno d'Aqueles cães malditos de Arquelau: (1) A antropofagia, como particularidade cultural brasileira, apresenta-se como metáfora da cena de saber; (2) A ideia de matriarcado, com a personagem Anna funcionando como "mãe" de um novo saber, atua como lugar da cena antropofágica; e (3) 
Eurípides, via Lutércio, atua como imagem de um espaço interdisciplinar que permite o encontro de outra verdade, uma verdade- mulher.

O movimento da "mancha biográfica" n'Aqueles cães malditos de Arquelau, suas motivações e finalidades, parece similar ao que se encontra num ensaio instigante da historiadora venezuelana Ligia Montañez, intitulado "Optar pela mãe (a partir de uma Ideia de Pedro Trigo)", que tem como um dos seus objetivos exatamente discutir o relacionamento do pesquisador latino-americano com seu objeto de pesquisa, tendo-se em vista sua posição, enquanto indivíduo, perante o pesquisador europeu no decorrer da história. Montañez (1991, p. 55), demarcando o privilégio do dado étnico em seu texto, começa por reconhecer, admirada, que questões como etnocentrismo, sociocentrismo, macrossociocentrismo e preferências culturais atualmente constituem "ameaças à firmeza epistemológica das ciências do comportamento humano".

Para a ensaísta, a forma com que os europeus articulam o conhecimento é um instrumento para o exercício do poder sobre continentes que foram colonizados por eles como a América Latina:

seus padrões [dos europeus] de conhecimento em geral e de conhecimento científico em particular tem sido conformados, através dos séculos, em seu próprio terreno; também têm sido para eles exitosos e, sem dúvida, instrumento fundamental em sua particular concepção e exercício do poder. Estrutura-se assim um quadro de autovalorização e, poderíamos acrescentar, sem competência (MONTAÑEZ, 1991, p. 55, tradução minha).

A maneira com que o europeu, na sua tarefa de conhecer, volta-se para os continentes do sul tem como finalidade aperfeiçoar a colonização, segundo Montañez:

seu [do europeu] conhecimento das culturas dos continentes do sul parte do fato expansionista e colonialista, trata-se de conhecer melhor o subalternizado para aperfeiçoar a colonização ou a neocolonização. De cara, há nesse conhecimento pelo menos um vício: a desqualificação - explícita ou implícita - do sujeito investigado, o qual exigiria a revisão desta subestimação desvalorizadora em cada caso concreto (MONTAÑEZ, 1991, p. 55, tradução minha).

Concentrando-se na América Latina, Montañez diz que o fato de nós, pesquisadores, termos compartilhado uma história de colonização de "similar origem" poderia favorecer "uma perspectiva menos curva para o conhecimento do 
outro-similar e para o mútuo conhecimento" (MONTAÑEZ, 1991, p. 55). Mas isso não tem ocorrido principalmente porque

em primeiro lugar o investigador social latino-americano está, em essência, formado dentro do modelo de "racionalidade ocidental" e, majoritariamente, essa racionalidade não é considerada como uma modalidade de razão, e sim como a racionalidade, quer dizer, a verdadeira; o valor máximo que adquire a razão humana é demonstrado, fundamentalmente, nessa sólida estrutura chamada ciência (MONTAÑEZ, 1991, p. 56, tradução minha)

Montañez, reportando-se à condição mestiça dos latino-americanos, critica o "rigor" metodológico, advindo da racionalidade ocidental, que exclui do trabalho de pesquisa a particularidade social, étnica e cultural do pesquisador. Ela se pergunta o que tem sido feito com a identidade do pesquisador no processo de pesquisa e "concretamente com o afetivo de nossa identidade" (MONTAÑEZ, 1991, p. 60). É diante da possibilidade de repressão dessa identidade e negação do diálogo direto com o "nuestro", no processo de pesquisa, que a ensaísta traz à tona a ideia de opção pela "mãe" de Pedro Trigo. Montañez cita Trigo:

A formulação paradigmática da contradição lationoamericana contém estes dois termos: o Pai europeu e mãe indígena ou negra. (...) Este paradigma cultural coexiste certamente com outros, mas expressa a nosso modo de ver a contradição principal (...) A resposta a essa contradição histórica pode ir em duas direções: apostar no Pai ou apostar na Mãe. Nosso juízo sobre ambas possibilidades é o seguinte: se se aposta no Pai, assume-se o pior do Pai e o pior da Mãe; se se aposta na Mãe, assume-se o melhor do Pai e o melhor da Mãe. Não se pode apostar nos dois ou em nenhum; essas alternativas não são historicamente viáveis porque em nível estrutural no só existe a separação entre os Pais (vencedores, senhores, opressores) e as Mães (vencidas, subalternas, oprimidas), mas esta separação é crescente. Há pois que se optar por um dos dois; se não se opta, opta-se pelo Pai já que, como a ordem está estabelecida em função do Pai, deixar-se levar é seguir sua lógica e manter-se em sua dinâmica. (MONTAÑEZ, 1991, p. 60, tradução minha) (grifo da autora)

Para Montañez (1991, p. 60, tradução minha),

Foi o pior do Pai o que prevaleceu séculos atrás nos fatos históricos que iniciaram nossa conquista, colonização e mestiçagem. Violência, opressão, racismo, escravidão, machismo. O melhor do branco fica minimizado com a imposição de tais elementos dentro do modelo social que se estabeleceu. Fica igualmente barrado o melhor da Mãe: 
amor, profundidade, dignidade, vida, imaginação, transcendência, e destacada a outra cara: servilismo, submissão, auto-repressão..

Penso que, n'Aqueles cães malditos de Arquelau, a "mancha biográfica" conduz o narrador Emílio à opção "por la Madre", que é a opção por Anna e, na sequencia, por um lugar diferente para a concepção do discurso científico. Essa opção é estimulada pelo conhecimento, via Lutércio, do enfoque da mulher, do mundo feminino, por Eurípides. Sobre Medéia, informa Lutércio, fundamentando sua defesa do trágico grego da acusação de misoginia:

\begin{abstract}
Mesmo na figura de Medéia, a mais dramática expressão da paixão descontrolada, Eurípides traça o perfil de uma mulher superior ao comum de seu tempo. Medeia é a primeira personagem feminina a assumir explicitamente o desejo do prazer e o direito ao afeto conjugal. Seria isso uma manifestação de misoginia? E o tema do desejo negado, como mola da vingança, percorre toda a tragédia, como um fio condutor, e não como situação particular ou como fala secundária da heroína. Tem o mesmo sentido o discurso dela às mulheres de Corinto. Para Aristófanes, talvez a confissão pública do desejo fosse uma indignidade a macular a figura feminina (...) É na acusação dele que se encontra quase uma prova de que Eurípides apresenta ao povo de Atenas um novo padrão de mulher, oposto ao perfil submisso e renunciatário que agradava a esse poeta sequioso de voltar aos tempos de Ésquilo. E é nessa negação, à mulher, do direito ao desejo e à paixão, travestida de defesa da honra feminina e até da graça da mulher, que se esconde uma visão misógina, que a quer confinada no lar, passiva, submissa e impedida de qualquer autonomia intelectual (...) Medéia é a primeira mulher a exercer essa autonomia e a defendê-la ante as mulheres do coro. Seria isso, em Eurípides, mostra de ódio às mulheres? $\mathrm{E}$ se note que Medéia é a primeira mulher a criticar, no teatro grego, a organização injusta da polis, que veda à mulheres até a atividade intelectual, literária e artística. Outra mostra de misoginia? (PESSOTTI, 1993, p. 115-116).
\end{abstract}

Emílio descobre o sabor.

\title{
5 Verdade, paixão e cães
}

Ao traduzir o texto de Lutércio sobre Eurípides, Emílio traz à tona a outra verdade que, no campo da ciência, tem sido buscada pela interdisciplinaridade. Trata-se da verdade que não é "a verdade", o ponto de vista absoluto, mas uma verdade possível. Eurípides, enquanto anunciador dessa outra verdade, passa a se colocar como um precursor da interdisciplinaridade. Creio que não seria demais pensar Eurípides como uma espécie de imagem originária de prática interdisciplinar, 
um anunciador da verdade apaixonada, o sabor do conhecimento, que está no âmago do projeto interdisciplinar - ele dá a medida da subversão da ordem do saber. Diz Emílio: "Ele (Eurípides) sabia que entre as coisas e as palavras há abismos e que a verdade é uma questão de discurso. Ainda mais. Ele sabia que a racionalidade é um sonho" (PESSOTTI, 1993, p. 156).

A interdisciplinaridade vem estimulando a reproposição da questão a respeito de quem realmente está com a verdade no âmbito do saber. Trata-se da emergência de uma das questões básicas na civilização ocidental: a palavra que veicula a verdade é a do poeta ou a do filósofo, a do artista ou a do cientista, a do louco ou a do gênio, enfim? Estas duas categorias representam a dicotomia inerente à cultura ocidental, a constante hesitação entre os polos da emoção e da razão, entre subjetividade e objetividade. Tal dicotomia é a representação de uma luta no decorrer dos séculos é travada no Ocidente entre Apolo e Dioniso, como afirma Camille Paglia (1993, p. 99):

No Ocidente, Apolo e Dioniso lutam pela vitória. Apolo faz as linhas de fronteira que são civilização mas conduzem a convenção, contenção, opressão. Dioniso é energia desenfreada, louca, rude, destrutiva, estróina. Apolo é a lei, a história, a tradição, a dignidade e a segurança do costume e da forma. Dioniso é o novo, emocionante mas rude, varrendo tudo para começar de novo. Apolo é um tirano. Dioniso um vândalo.

A interdisciplinaridade parece que tende cada vez mais a resgatar a verdade que vinha da palavra do poeta, o aedo da Grécia antiga, a verdade que era "alétheia", aquela que foi "soterrada" pela verdade que se impôs através da palavra do filósofo, conforme Luiz Alfredo Garcia-Roza (1990, p. 25):

Muito tempo antes do homem ocidental inventar o conhecimento, de opor o verdadeiro e o falso no interior do discurso, a cultura grega já era atravessada pela noção de alétheia: a verdade, para o poeta da Grécia arcaica. À pré-histórica da verdade filosófica corresponde uma verdade poética que foi o solo a partir do qual ou contra o qual se organizou o pensamento filosófico grego.

Aprofundando a discussão deste assunto, Garcia-Roza revela três tipos de buscadores da verdade: o filósofo platônico, cujo discurso era legitimado pela "obediência ao princípio da não-contradição", o pensador religioso, que entendia que "o caminho para a verdade é o caminho para Deus", e o amante que, conforme 
Deleuze depreende de À la recherche du temps perdu de Proust, é aquele que decifra os signos da amada, que percebe uma dissimulação, um ocultamento, uma mentira nos seus gestos, nas suas palavras, nos seus silêncios" (GARCIA-ROZA, 1990, p. 17). A respeito deste terceiro buscador da verdade, comenta ainda o ensaísta:

\begin{abstract}
A verdade não resulta da aplicação de um método, mas é o efeito de encontros que se dão ao acaso. A verdade à qual chegamos pela aplicação rigorosa do método é uma verdade puramente lógica, abstrata, em tudo diferente daquela a que chega o amante ao decifrar os signos da amada. A verdade não é obra da inteligência pura, na medida que esta última é uma atividade voluntária operando segundo uma boa vontade do pensador, mas sim o resultado de uma violência feita a essa boa vontade. Não chegamos à verdade através de uma série de doces encadeamentos lógicos, mas somos compelidos a buscá-la, premidos por uma necessidade que nada tem a ver com a necessidade da lógica filosófico-científica (GARCIAROZA, 1990, p. 20)
\end{abstract}

\title{
Considerações finais
}

Parece-me plausível pensar esse terceiro buscador da verdade, o amante, como metáfora do pesquisador que opera atualmente a partir do viés da interdisciplinaridade. Esse pesquisador-amante sabe que "a mulher amada é muito mais rica em signos do que o mais complexo tratado científico" (GARCIA-ROZA, 1990 , p. 20), motivo pelo qual se desvia do comportamento tradicional do cientista, suspende a suposta imparcialidade do método pela parcialidade do olhar, sai da ditadura do saber e entra na democracia do sabor. Sabe também que para revelar a sua verdade, a verdade do apaixonado pelo conhecimento, é preciso mudar o seu discurso, alterar radicalmente a sua linguagem, extirpando-lhe qualquer vontade de poder. Como nota Izidoro Blikstein, ao discutir uma questão de suma importância,

a linguagem deixa de ser fascista quando, subvertendo a si mesma, subverte a percepção/cognição (...) para chegar a essa subversão seria preciso cultivar a função poética da linguagem (...) é pela função poética que a linguagem pode subverter a sua estereotipia e entrar numa relação conflituosa e dialética com a práxis (BLIKSTEIN, 1995, p. 84-85).

Entretanto, esse pesquisador-amante sabe, sobretudo, que, no âmbito acadêmico, só pode ir até o limite da interdisciplinaridade, que fatalmente vai 
esbarrar nas muralhas protetoras da ciência, na lógica ocidental. Se ultrapassar esse limite, estará correndo um sério risco de, como Eurípides, ser estraçalhado pelos cães de Arquelau, pelos princípios da razão institucional. A interdisciplinaridade é, sem dúvida, uma prática muito perigosa.

\section{Referências}

ANDRADE, Oswald de. A utopia antropofágica. São Paulo: Globo, 1990.

BARTHES, Roland. O rumor da língua. Trad. Leyla Perrone-Moisés. São Paulo: Brasiliense, 1988.

O prazer do texto. Trad. J. Guinsburg. São Paulo: Perspectiva, 1977.

. O grau zero da escritura. Trad. Heloísa Dantas. São Paulo: Cultrix, 1976.

BENJAMIN, Walter. Charles Baudelaire: um lírico no auge do capitalismo. Trad. José Carlos Martins Barbosa e Hemerson Alves Baptista. 3.ed. São Paulo: Brasiliense, 1994.

BLIKSTEIN, Izidoro. Kaspar Hauser ou a fabricação da realidade. 4. ed.São Paulo: Cultrix, 1995.

BRUNA, Jaime. In: Platão. Diálogos. Trad. Jaime Bruna. São Paulo: Cultrix, 1991.

CIORAN, Émile. História e utopia. Trad. José Thomaz Brum. Rio de Janeiro: Rocco, 1994.

FAZENDA, Ivani C. Arantes. Interdisciplinaridade: história, teoria, pesquisa. Campinas, SP: Papirus, 1994.

FOUCAULT, Michel. As palavras e as coisas: uma arqueologia das ciências humanas. Trad. Selma Tannus Muchail. São Paulo: Martins Fontes, 1987.

GARCIA-ROZA, Luiz Alfredo. Palavra e verdade na filosofia antiga e na psicanálise. Rio de Janeiro: Jorge Zahar Editor, 1990.

JAMESON, Frederic. Periodizando os anos 60. In: HOLLANDA, Heloísa Buarque de. Pós-modernismo e política. 2.ed. Rio de Janeiro: Rocco, 1992.

LIMA, Luiz Costa. Sociedade e discurso ficcional. Rio de Janeiro: Guanabara, 1986.

MIRANDA, Wander Melo. Ficção virtual. Aletria: Revista de Estudos de Literatura. Belo Horizonte, v. 3, p. 9-19, outubro 1995. Disponível em: <http://www.periodicos. letras.ufmg.br/index.php/aletria/article/view/1110/1211>. 
$\mathbb{B}_{\text {disse }} \mathcal{A}$

MONTAÑEZ, Ligia. Optar por la madre (a partir de una Idea de Pedro Trigo). In: Revista Casa de las Americas. La Habana: Casa de las Américas, octubredeciembre 1991.

PAGLIA, Camille. Personas sexuais - arte e decadência de Nefertite a Emily Dickinson. Trad. Marcos Santana. São Paulo: Companhia das Letras, 1993.

PESSOTTI, Isaías. Aqueles cães malditos de Arquelau. 4. ed Rio de Janeiro: Editora 34, 1993.

SANTOS, Laymert Garcia dos. Tempo de ensaio. São Paulo: Companhia das Letras, 1989. 